\title{
TELAAH YURIDIS PENERAPAN SANKSI DI BAWAH MINIMUM KHUSUS PADA PERKARA PIDANA KHUSUS
}

\author{
Oheo K. Haris \\ The School of Law, University of Halu Oleo, Kendari, Indonesia
}

\begin{abstract}
ABSTRAK:
Penelitian ini dilaksanakan di Pengadilan Negeri di lingkungan Provinsi Daerah Istimewa Yogyakarta yang meliputi Pengadilan Negeri Sleman, kota Yogyakarta dan Bantul. Pengadilan tersebut dipilih dengan pertimbangan terdapat beberapa perkara yang menyangkut tindak pidana khusus. Tujuan penelitian : (1) untuk mengetahui apakah hakim boleh menjatuhkan sanksi di bawah standar minimum khusus pada perkara pidana khusus dan (2) untuk mengetahui apa dasar yuridis pemikiran hakim dalam menjatuhkan sanksi pidana di bawah minimum khusus pada perkara pidana khusus. Untuk mencapai tujuan tersebut, maka penelitian dilaksanakan dengan menggunakan rancangan penelitian hukum. Sampling meliputi subjek sampling yang ditentukan secara purposive. Bahan hukum terdiri dari: bahan hukum primer dan sekunder yang dikumpulkan melalui wawancara dan dokumentasi. Analisis dilakukan secara kualitatif. Hasil penelitian menunjukan : (1) Peranan hakim dalam penerapan sanksi minimum dalam tindak pidana khusus pada proses peradilan pidana sangat besar, yaitu sebagai pemberi putusan akhir, hakim berpedoman pada peraturan perundang-undangan. Dengan demikian, maka penulis berpendapat bahwa hakim tidak boleh menjatuhkan sanksi di bawah standar minimum. Dengan alasan bahwa negara Indonesia menganut Sistem Kontinental yakni hakim (sebagai pedoman pemidanaan) terikat oleh undangundang (aliran konservatif). Hal tersebut, sebagai realisasi asas the binding persuasive of precedent. Selain itu, konteks sanksi minimum yang terdapat dalam rumusan pasal terhadap tindak pidana khusus, secara terang dan jelas, terdapat pernyataan sanksi pidana yang memuat ketentuan maksimal dan minimal, sehingga tidak memerlukan penafsiran lanjutan. (2) Selain mengacu Pasal 103 KUHP dan 284 ayat (1) dan (2) KUHAP, dasar yuridis penerapan sanksi, hakim mengacu pada peraturan perundangundangan tindak pidana khusus yang mengatur ketentuan minimum khusus. Selain kedua pasal di atas, yurisprudensi dapat digunakan sebagai dasar yuridis dalam penjatuhan sanksi, dengan catatan, tetap mengacu ketentuan minimum sekurang-kurangya sama atau di atas minimum.
\end{abstract}

Katakunci : Penerapan Sanksi dan Pidana Khusus 


\title{
THE JURIDIS STUDY OF SANCTION APPLICATIONS UNDER SPECIAL MINIMUM ON SPECIAL CREDIT CODES
}

\author{
Oheo K.Haris \\ The School of Law, University of Halu Oleo, Kendari, Indonesia
}

This research was carried out in the District Court in the Province of Yogyakarta Special Region covering the District Court of Sleman, the city of Yogyakarta and Bantul. The court was chosen with consideration of several matters involving special crimes. The objectives of the study are: (1) to determine whether a judge may impose sanctions below minimum standards specifically on special criminal cases and (2) to find out what the judicial mind's juridical grounds in imposing criminal sanctions are below a special minimum on special criminal cases. To achieve these objectives, the research was conducted by using the research design law. Sampling includes the subject of sampling which is determined purposively. Legal material consists of: primary and secondary legal materials, they were collected through interviews and documentation. The analysis was done qualitatively. The results of the research show: (1) the judge had a big role in the application of minimum sanction in a special criminal act in the criminal justice process, namely as the final decision maker, the judge is guided by the legislation. Thus, the researcher argues that the judge should not impose sanctions below minimum standards. For that reason, the Indonesian state embraces the Continental System ie the judge (as a guideline of punishment) is bound by the law (conservative school). That is, as the realization of the binding persuasive principle precedent. In addition, the context of minimum sanctions contained in the formulation of the article on specific criminal acts, clearly contain statement of criminal sanctions containing the provisions of the maximum and minimum, so it does not require further interpretation. (2) In addition to referring to Article 103 of the Criminal Code and 284 paragraphs (1) and (2) of the Criminal Procedure Code, the juridical basis for the application of sanctions, judges refer to special criminal law legislation governing special minimum provisions. In addition to the above two chapters, jurisprudence may be used as a juridical basis in the imposition of sanctions, with a note, still referring to the minimum requirement of at least equal to or above the minimum.

Keywords: Application of Special Penalties and Crimes

\section{LATAR BELAKANG}

Dalam rangka penegakan hukum law enforcement terdapat kehendak agar hukum tegak, sehingga nilai-nilai yang diperjuangkan melalui instrument hukum yang bersangkutan dapat diwujudkan. Sedangkan dalam menggunakan hukum, citacita yang terkandung dalam hukum belum tentu secara sungguh-sungguh hendak diraih, sebab hukum tersebut digunakan untuk membenarkan tindakan-tindakan yang dilakukan to use the law to legitimate their actions.

Dalam praktik, penegakan hukum melibatkan keahlian professional dalam bidang hukum. Setelah keahlian 
berkolaborasi dengan keahlian dan kekuasaan, maka hukum dapat dijadikan pembenar untuk tindak kekerasan, diskriminasi, dan bahkan untuk meraih keuntungan yang sebenarnya tidak sah (korupsi). Dengan menggunakan hukum, korupsi dapat menjadi sempurna. Tidak terlacak seperti kebanyakan korupsi di peradilan. Hal tersebut sering serjadi di wajah dunia peradilan. Ada asas hukum yang menyatakan bahwa hakim lebih baik membebaskan orang yang bersalah daripada menghukum orang yang tidak bersalah. $^{1}$

Dengan ketentuan tersebut diatas menarik untuk mengupas tentang kemandirian hakim dalam peranannya menerima, memeriksa dan mengadili perkara yang menjadi wewenangnya, terutama terhadap kasus-kasus pidana khusus. Hakim mempunyai kedudukan yang strategis dalam politik kriminal guna menanggulangi kejahatan tersebut dan menciptakan perlindungan serta kesejahtraan masyarakat. Dalam kenyataannya banyak dijumpai adanya disparitas pidana yang disebabkan terutama karena faktor hakim. Banyak putusan yang tidak sebanding mengenai berat ringannya pidana meskipun terhadap perkara yang sejenis atau

${ }^{1}$ Soelidarmi, S.H. ,Kumpulan Putusan Kontraversial dari Hakim/Majelis Kontraversial, UII Press, Yogyakarta, 2002. dikutip dari Soelidarmi (Wakil Ketua PN Sleman), Sering Dituding Hakim Kontraversial, Harian Bernas, Senin Pon 3 Desember 2001, hal ix dapat disebandingkan. Masyarakat sering membandingkan antara pencurian dan korupsi yang kelihatannya hampir sepadan yakni sama-sama mengambil barang milik orang/pihak lain, tetapi sangat berbeda putusan pidananya, bahkan ada kalanya terhadap kasus korupsi dengan kerugian negara dalam skala besar namun terdakwanya bebas.

Sehubungan dengan masalah disparitas pidana, Muladi berpendapat bahwa yang dikehendaki bukanlah putusan yang sama terhadap perkara yang sama, tetapi adanya rasionalitas dalam pertimbangan yang dijadikan dasar putusan terhadap perkara yang bersangkutan. Dengan demikian akan dihasilkan putusan yang rasional dan dapat diterima banyak pihak. Lebih lanjut $\mathrm{Mu}-$ ladi menulis :

Namun yang terlebih penting adalah, perlunya penghayatan asas proporsionalitas dalam penjatuhan pidana, yakni proporsionalitas atas kepentingan masyarakat, kepentingan negara, kepentingan si pelaku tindak pidana dan kepentingan korban tindak pidana. Yang dikehendaki bukan paritas pidana (parity sentencing) seperti dianut oleh aliran klasik melainkan sejauh mana pidana tersebut cukup beralasan atas dasar pedoman pemidanaan. $^{2}$

Kasus-kasus yang terjadi di atas dapat di kategorikan sebagai pidana khusus yang disidangkan dengan pengadilan khusus pula. Hal ini diatur dalam penjelasan Pasal

\footnotetext{
${ }^{2}$ Gregorius Aryadi, Putusan Hakim Dalam Perkara Pidana, Universitas Atma Jaya Yogyakarta, 1995, hal 3-5.
} 
15 ayat 1 Undang-Undang Keuasaan Kehakiman yang berbunyi "Yang dimaksud dengan "Pengadilan Khusus" dalam ketentuan tersebut, antara lain, adalah pengadilan anak, pengadilan niaga, pengadilan hak asasi manusia, pengadilan tindak pidana korupsi, pengadilan hubungan industrial yang berada di lingkungan peradilan umum, dan pengadilan pajak di lingkungan peradilan tata usaha Negara". ${ }^{3}$

Ketentuan sanksi pidana khusus ketika hakim memutuskan dengan sanksi maksimum dan minimum, namun yang terjadi adalah sering kali terjadi bahwa putusan itu tidak sampai pada ketentuan standar minimum. Disinilah sering terjadi putusan kontraversi antara pertimbangan rasio hakim untuk kepentingan terdakwa dengan rasa keadilan dalam masyarakat. Padahal ketentuan sanksi dalam pidana khusus itu sudah jelas-jelas ditegaskan bahwa adanya ketentuan standar maksimum dan minimum yang kemudian menjadi pegangan/patokan/pedoman hakim dalam memutus perkara.

Kemudian apakah kemadirian kekuasaan kehakiman mempunyai implikasi terhadap penegakkan hukum oleh hakim di muka persidangan. Sudah jelas

3 Bambang Sutiyoso, Sri Hastuti Puspitasari, Aspek-aspek Perkembangan Kekuasaan Kehakiman Di Indonesia, Pengatar: Prof.Dr. Jimly Asshidqi, Penjelasan atas Undang-undang Republik Indonesia Nomor 4 Tahun 2004 Tentang Kekuasaan Kehakiman, UII Press, Yogyakarta, 2005, hal 166 implikasinya besar, karena sikap hakim dalam proses peradilan akan sangat menentukan obyektifitas dalam memutuskan suatu perkara. Bahkan Sahlan Said, S.H., seorang hakim senior dari pengadilan Negeri Magelang, dalam tulisannya menyatakan bahwa satu-satunya jabatan atau profesi yang dapat mewakili Tuhan kiranya adalah hanya hakim, sebab otoritas yang diberikan kepadanya bukan sekedar memenjara tetapi juga dapat mencabut nyawa seseorang. ${ }^{4}$ Beberapa ungkapan yang memberikan kedudukan istimewa kepada hakim misalnya, adalah benteng terakhir bagi pencari keadilan, selain itu hakim juga merupakan Ultimum Remedi$u m$, yang menjadi senjata pamungkas bagi semua ketidakberesan, karena itu ada ungkapan yang cukup ekstrim bahwa semua bagian masyarakat boleh rusak asalkan hakimnya tidak semuanya akan menjadi beres. ${ }^{5}$

Majelis hakim yang mempunyai integritas moral yang tinggi dalam mempertahankan kemandiriannya, akan dapat berfungsi sebagai penegak hukum yang baik dalam menjalankan tugas dan wewenang

\footnotetext{
4 Bambang Sutiyoso, Sri Hastuti Puspitasari, Aspek-aspek Perkembangan Kekuasaan Kehakiman Di Indonesia, dikutip dari Sahlan Said,S.H,Kemandirian Kekuasaan KehakimanPengalaman Praktek Menuju Kemandirian Hakim Tolok Ukur dan Kendalanya, Seminar 50 Tahun Kemandirian Kekuasaan Kehakiman di Indonesia di Universitas Gadjah Mada Tanggal 26 Agustus 1995, UII Press, Yogyakarta, 2005, hal 87.

${ }^{5}$ Ibid, hal 87
} 
yudisialnya. Sehingga selama penyelenggaraan proses peradilan, mulai dari pemeriksaan peristiwanya, pembuktian sampai pada putusan yang dijatuhkan, majelis hakim selalu berpedoman pada prinsip-prinsip yang dan dapat dipertanggunjawabkan. Putusan hakim pun akan mempunyai tingkat kualitas yang memadai. Para pihak yang berperkara selaku pencari keadilan juga cenderung akan menerima putusan yang telah dijatuhkan, bahkan dengan sukarela akan melaksanakan putusan tersebut, karena dianggap sudah sesuai dengan persaan keadilan masyarakat. ${ }^{6}$

Ketentuan standar maksimum dan minimum nampaklah dapat lihat bahwa adanya kecenderungan dari pembentuk undangundang pada tahap regulasi belum terlihat keseriusan dalam menentukan "Public Policy" dan "sentencing policy" yang kemudian menjadi masalah sentral dalam kebijakan hukum pidana. ${ }^{7}$

${ }^{6}$ Ibid, hal 88

${ }^{7}$ Barda Nawawi Arief, Bunga Rampai Kebijakan Hukum Pidana, Citra Aditya Bakti, Bandung, 2002. Dalam bukunya, masalah sentral dalam kebijakan hukum pidana. (1). Tahap formulasi atau "kebijakan legislatif merupakan tahap awal yang strategis dalam kebijakan hukum pidana atau keseluruhan proses kebijakan penanggulangan kejahatan dengan sarana hukum pidana (penal). (2). Ada dua masalah sentral dalam kebijakan hukum pidana (tahap formulasi atau kebijakan legislatif yaitu: (a). Masalah penentuan perbuatan apa yang seharusnya dijadikan sebagai tindak pidana. (b). Masalah penentuan sanksi apa yang sebaiknya digunakan atau dikenakan terhadap si pelaku tindak pidana.
Berbagai putusan hakim yang senantiasa memutuskan dibawah minimum yang mengakibatkan putusan tersebut telah terjadi inkonsisten sebagaimana yang telah diatur dalam undang-undang. Penjatuhan sanksi terhadap putusan yang ideal dapat memberikan rasa kepastian hukum dan rasa keadilan dalam masyarakat, meskipun sudah ada sebuah teori yang membenarkan disamping itu pula bahwa hakim dapat dikatakan sebagai corong undang-undang. Tanpa adanya konsistensi dalam memutuskan perkara pidana khusus yang jelas maka, aturan yang telah ditetapkan dalam undang-undang tersebut akan menemukan rasa ketidakadilan dan ketidakpastian hukum dalam masyarakat, bahkan seolaholah ada teori baru yang membenarkan bahwa hakim dapat menciptakan teori baru. Padahal dalam bukunya Sudikno Mertokusumo, bahwa seorang hakim harus menggali hukum kepermukaan, bukanlah menciptakan hukum baru.

Berdasarkan uraian tersebut diatas dapat dirumuskan persoalan sebagai berikut;

\section{PERUMUSAN MASALAH}

Berdasarkan latar belakang tersebut, maka yang mejadi rumusan masalah dalam penelitian ini adalah sebagai berikut :

1. Apakah seorang Hakim boleh menjatuhkan sanksi pidana dibawah minimum khusus yang telah ditentukan undang-undang? 
2. Apa dasar yuridis pemikiran Hakim menjatuhkan sanksi pidana di bawah minimum khusus?

\section{METODE PENELITIAN}

\section{Metode Pendekatan}

Karena penelitian ini termasuk hukum normatif, pendekataanya menggunakan pendekatan normatif analisitis, dengan mengikuti langkah-langkah sebagai berikut:

a. Mengidentifikasi sumber hukum yang menjadi dasar rumusan masalah;

b. Mengidentifikasi pokok bahasan dan sub pokok bahasan yang bersumber dari rumusan masalah;

c. Mengidentifikasi dan menginnventarisasi ketentuan-ketentuan normatif bahan hukum primer dan bahan hukum skunder berdasarkan rincian subpokok bahasan;

d. Mengkaji secara komprehensif analistis bahan hukum primer dan bahan skunder guna menjawab permasalahan yang telah dirumuskan;

e. Hasil kajian sebagai jawaban permasalahan dideskripsikan secara lengkap, rinci, jelas, dan sistematis dalam bentuk laporan hasil penelitian atau karya tulis ilmiah.

\section{Spesikasi Penelitian}

Spesifikasi dalam metode penelitian ini menggunakan yuridis normatif-empiris yang menggunakan data skunder dan datan primer. Tipe penelitian hukumnya adalah kajian komprehensif analistis terhadap bahan hukum primer dan bahan hukum skunder. Hasil kajian dipaparkan secara lengkap, jelas, sistem sebagai karya ilmiah.

\section{Metode Sampling}

Metode sampling yang digunakan dalam penelitian ini adalah para hakim pengadilan negeri yang pernah memeriksa dan memutus perkara di bawah minimum, yang ditunjuk oleh pengadilan negeri yang bersangkutan untuk menjadi responden dalam penelitian ini. Teknik pengambilan sampel yang digunakan yaitu non random, yaitu tidak mengambil sampel yang sama dalam suatu populasi dan merupakan jenis purposive, yaitu didasarkan pada kreteria tertentu yang dipertimbangkan untuk memilih sampel.

\section{Metode Pengumpulan Data}

Karena penelitian ini tergolong penelitian hukum normatif, maka data yang diperlukan hanya data skunder. Data skunder yang diperlukan itu adalah bahan hukum primer yang bersumber dari sumber primer, yaitu perundang-undangan yang relevan dengan rumusan masalah yang berupa:

\section{a. Data Primer}

Data yang diperlukan dalam penelitian ini dilakukan dengan cara penelitian langsung dari objeknya dilakukan dengan cara :

1. Observasi 
Data yang diperoleh dengan cara menelaah sumber-sumber tertentu yang terkait dengan judul penelitian.

2. Wawancara

Wawancara yang dilakukan terhadap Hakim di Pengadilan Negeri Sleman Daerah Istimewa Yogyakarta.

\section{b. Data Sekunder}

Yaitu data yang diperoleh dari studi pustaka. Data sekunder dalam penelitian ini dikelompokkan menjadi tiga kategori yaitu:

1. Bahan Hukum Primer

Yaitu bahan hukum yang terdiri dari :

a. Kitab Undang-undang Hukum Pidana

b. Kitab Undang-undang Hukum Acara Pidana.

c. Undang-Undang Nomor 48 Tahun 2009 Tentang Kekuasaan Kehakiman

d. Undang-undang Nomor 5 Tahun 2004 Tentang Perubahan Atas Undang-undang Nomor 14 Tahun 1985 Tentang Mahkamah Agung.

e. Undang-Undang Nomor 31 Tahun 1999 jo Undang-Undang Nomor 20 Tahun 2001 tentang Tindak Pidana Korupsi.

f. Undang-Undang Nomor 5 Tahun 1997 Tentang Psikotropika

g. Undang-Undang Nomor 9 Tahun 1976 Tentang Narkotika sebagaimana telah diubah dengan Undang-Undang Nomor 35 Tahun 2009 Tentang Narkotika

h. Undang-Undang Nomor 39 Tahun 1999 Tentang Hak Asasi Manusia

i. Undang-Undang Nomor 23 Tahun 2002 Tentang Perlindungan Anak

j. Peraturan perundang-undangan yang berkaitan dengan masalah yang diteliti, yaitu pidana khusus.

2. Bahan Hukum Sekunder
Yaitu bahan hukum yang memberi penjelasan bagi bahan hukum primer, terdiri dari :

a. buku-buku literatur ilmu hukum dan putusan-putusan Hakim di Pengadilan Negeri Sleman DIY Yogyakart.

b. Dokumen dan tulisan-tulisan hukum lainnya yang relevan dengan rumusan masalah.

3. Bahan Hukum Terseir

Bahan hukum yang memberi petunjuk dan penjelasan terhadap bahan hukum primer dan bahan hukum sekunder.

\section{Metode Analisis Data}

Analisis data dalam penelitian ini meliputi sumber primer, yaitu perundang-undangan yang relevan dengan permasalahan; sumber skunder, yaitu buku-buku literatur ilmu hukum serta tulisan-tulisan hukum lainnya yang relevan dengan permasalahan. Studi pustaka dilakukan melalui tahap-tahap identifikasi pustaka sumber data, identifikasi bahan hukum yang diperlukan, dan inventarisasi bahan hukum (data) yang diperlukan tersebut. Data yang sudah terkumpul kemudian diolah melalui tahap pemeriksaan (editing), penandaan (coding), penyusunan (reconstructing), sistematisasi berdasarkan pokok dan subpokok bahasan yang identifikasi dari rumusan masalah (systematizing).

HASIL PENELITIAN

A. Peranan Hakim Dalam Menerapkan Sanksi Pidana Minimum Khusus Menurut Ketentuan UndangUndang. 
Hakim menjatuhan sanksi pidana selalu mengacu pada Kitab Undangundang Hukum Pidana (KUHP) yakni dengan menggunakan sistem minimum khusus dan maksimum umum serta dengan minimum umum tanpa mengatur sistem khususnya, sehingga dampak dari putusan yang dijatuhkan dalam persidangan (inkracht van gewijsde) yang merupakan putusan yang berkekuatan hukum tetapi kadangkala menimbulkan rasa ketidakadilan, dikarenakan seringnya hakim dalam menjatuhkan vonis suatu perkara pidana sangat ringan (di bawah standar minimum) dibandingkan dengan kejahatan dan akibat dari kejahatan tersebut.

Sebagaimana dijelaskan dalam tinjauan pustaka bahwa KUHP hanya menetapkan maksimum umum dan maksimum khusus serta minimum umum, Pasal 12 ayat (2) KUHP menyatakan bahwa pidana penjara selama waktu tertentu paling singkat adalah 1 (satu) hari dan paling lama 15 (lima belas) tahun berturut-turut. Kemudian dalam Pasal 18 ayat (1) KUHP menyatakan bahwa pidana kurungan paling singkat adalah 1 (satu hari) dan paling lama adalah 1 (satu) tahun, sedangkan pidana denda tidak ada ketentuan maksimum umumnya. Kedua pasal tersebut hanya mengatur ketentuan maksimum umum dan minimum umum dalam KUHP, kemudian maksimum khususnya terdapat dalam pasal- pasalnya tanpa mengatur minimum khususnya.

Ketentuan maksimum umum dalam KUHP untuk pidana penjara adalah selama 15 (lima belas) tahun berturut-turut dan untuk pidana kurungan selama 1 (satu) tahun sedangkan ketentuan mengenai minimum umum dalam KUHP untuk pidana penjara adalah selama 1 (satu) tahun dan untuk pidana kurungan adalah selama 1 (satu) hari. Pengaturan sistem minimum, maksimum umum, dan khusus serta sistem minimum khusus, maka hakim dalam menjatuhkan pidana dapat bergerak antara pidana yang tertinggi dan yang paling rendah.

Dalam sistem maksimum yang terdapat dalam KUHP terdapat pengaturan tentang penyertaan (delneeming), percobaan (poging), perbarengan (concursus), pengulangan (recidive) dengan alasan pemberatan dan peringanan pidana, dalam penjatuhan pidananya dapat diperberat dan diperingan, sedang dalam sistem minimum khusus tidak terdapat pedoman yang mengatur mengenai hal tersebut. Berbagai ancaman sanksi pidana yang tercantum dalam KUHP, maka sering diterapkan ancaman alternatif dalam satu pasal. Di samping itu, tidak terdapat sistem minimum khusus dalam tiap-tiap pidana yang mencantumkan pasal-pasal tersebut, maka hakim mempunyai kebebasan yang sangat luas dalam menentukan berat- 
ringannya pidana, akibat dari ketentuan tersebut, akan menimbulkan disparitas putusan. Salah satu kelebihan dicantumkannya sistem minimum khusus dalam setiap pasal, sebagai contoh penjelasan dalam Undang-Undang Nomor 31 Tahun 1999 dan Undang-undang Nomor 20 Tahun 2001 tentang Pemberantasan Tindak Pidana Korupsi adalah mengurangi adanya disparitas pidana karena hakim memiliki pedoman yang jelas dalam menjatuhkan sanksi, berat-ringannya sanksi pidana yang dijatuhkan sebanding dengan kejahatan dan akibat kejahatan tersebut.

\section{B. Boleh Tidaknya Hakim Memutus Di Bawah Sanksi Minimum.}

Mengenai ketentuan sanksi minimum telah diatur pada masing-masing tindak pidana khusus. Dalam tahap aplikasi, pada perkara pidana khusus sebagaimana didakwakan penuntut umum kepada terdakwa, ternyata terdapat beberapa hakim (dengan pertimbangan hukum tertentu) yang menjatuhkan pidana di bawah batas/limit ancaman pidana minimal khusus dalam rumusan deliknya, bila dikaitkan dengan legislasi (pembuat undang-undang) bahwa ditetapkannya pidana minimum khusus untuk delik-delik tertentu untuk mendukung asas-asas hukum pidana.
Pada tingkatan aplikasi, baik putusan maksimum dan minimum pada suatu putusan pidana yang dijatuhkan hakim dapat membawa dampak luas, tidak hanya bagi pelaku tindak pidana yang bersangkutan, tetapi juga bagi korban dan masyarakat. Hal tersebut dalam proses penjatuhan pidana, di samping bersentuhan dengan aspek yuridis, juga bererkaitan dengan aspek sosiologis dan filosofis.

Sebagaimana dikemukakan dalam landasan teori bahwa kaidah hukum suatu putusan pidana, idealnya harus memenuhi ketiga macam unsur yaitu: landasan yuridis, sosiologis, dan filosofis. Hakim menggunakan metode analisis yuridis komprehensif untuk memecahkan hukum dari perkara yang ditanganinya. Aspek yuridis sebagai pendekatan pertama dan utama yaitu sesuai dengan ketentuan perundang-undangan yang berlaku, pendekatan filosofis yaitu berintikan pada kebenaran dan rasa keadilan, sedangkan pendekatan sosiologis yaitu sesuai dengan tata nilai budaya yang berlaku di masyarakat.

Menurut Joni ${ }^{8}$, penerapan sanksi minimum pada perkara tindak pidana khusus contohnya kasus korupsi, bila mengacu pada peraturan perundang-undangan tetap mempertimbangkan dua sisi objektif dan subjektif. Dari sisi objektif, dipaparkan

${ }^{8}$ Hasil wawancara, Hakim Pengadilan Negeri Sleman, tanggal 2 Februari.2009 
bahwa landasan filosofi terhadap perbuatan korupsi adalah mencegah kerugian negara, di samping itu, melihat berapa kerugian negara yang dikorupsi. Dari sisi subjektif, hakim menilai pada perbuatan terdakwa yakni melihat pada tingkat kesalahannya terhadap penyalahgunaan kewenangan sebagaimana tercantum dalam Pasal 3 Undang-undang Nomor 31 Tahun 1999 jo Undang-undang Nomor 20 Tahun 2001. Selanjutnya, dari tingkat kesalahan tersebut kemudian dipresentasikan seberapa banyak yang dikorupsikan oleh masing-masing terdakwa, setelah itu, diterapkan berapa tahun yang divonis pada masing-masing terdakwa.

Secara prinsipil, penerapan sanksi minimum menurut Joni, tetap mengacu pada standar minimum khusus, walaupun terdapat sebagian hakim menjatuhkan di bawah standar minimum. Ketentuan syarat pokok dan syarat tambahan harus dipisahkan, sehingga dalam Pasal 2 undang-undang korupsi hanya pada orang yang mempunyai kedudukan sebagai penyelenggara negara. Pasal 3 hanya diperuntukan pada pegawai negeri sipil (PNS) biasa, karena tidak mempunyai kedudukan, walaupun korupsi dilakukan dengan jumlah yang kecil, tetapi dilakukan secara terus-menerus, sehingga dapat merugikan negara dengan jumlah yang sangat besar.
Joni memandang bahwa ancaman standar minimum Pasal 3, seyogyanya mempunyai kesamaan dengan ancaman pada Pasal 2. Menurut responden bahwa ancaman standar minimum khususs pada Pasal 3 harus lebih tinggi standar atau minimalnya sama dengan Pasal 2.

Dalam perkara narkotika dan psikotropika, Joni mengungkapkan bahwa tindak pidana khusus belum memberikan batasan pengertian khususnya pada undang-undang tentang narkoba. Menurutnya dalam menafsirkan undangundang terdapat perbedaan antara pengertian awam dan pengertian hukum.

Menurut V. Banar menyatakan bahwa dalam memutus sanksi pidana di bawah minimum memberikan vonis 2 (dua) tahun penjara dengan nomor: 150/pid.B/2007/PN Bantul atas nama Kusrianto pada kasus korupsi proyek perumahan pasca gempa di Kabupaten Bantul senilai Rp.120.000.000,- dengan dasar yuridis Pasal 2 Undang-undang Korupsi Nomor 31 Tahun 1999 jo Nomor 20 Tahun 2001. Putusan tersebut didasarkan atas pertimbangan rasa keadilan dan nilai kerugian yang dikorupsi sebesar Rp.9.000.000,-. Tujuan pemberian vonis tersebut adalah untuk memberikan efek jera dan tidak terlalu jauh dengan disparitas putusan.

Selanjutnya, dikemukakan bahwa boleh tidaknya pengambilan keputusan 
atau vonis yang diberikan untuk kasus tersebut dengan mengambil putusan di bawah minimum khusus, menurut $\mathrm{V}$. Banar menyatakan boleh menjatuhkan sanksi di bawah standar minimum dengan melihat beberapa faktor dan kondisi terdakwa, di antaranya psikologis kemanusian dan nilai kerugian serta halhal meringankan terdakwa.

V. Banar menganjurkan bahwa tidak perlu memakai ancaman minimal dan denda kerugian harus dikurangi. Selain perlu dikaji kembali mengenai ketentuan minimum dan maksimum pada pembahasan legislasi, sebagian tindak pidana tersebut seyogyanya dapat dihapuskan sanksi minimumnya, sehingga penafsiran hukum dapat diberikan seluasluasnya kepada hakim.

Ketentuan mengenai boleh tidaknya memutus di bawah standar minimum khusus, sebagian hakim menyatakan tidak setuju. Hal tersebut, dinyatakan hakim Rangkilemba yang tetap mengacu pada peraturan standar di bawah minimum (undang-undang), walaupun keputusan hakim telah diberikan kewenangan seluasluasnya, sebagaimana termaktub dalam penjelasan undang-undang kekuasaan kehakiman. Menurutnya, tujuan diterapkannya sanksi standar minimum yaitu memberikan pedoman pada hakim untuk menilai dan mempertimbangkan batas hukuman yang akan dijatuhkan, sehingga dengan dasar pedoman tersebut, maka dapat membantu hakim memutus perkara pidana khusus dengan putusan yang adil dan memenuhi kepastian hukum. Standar minimum khusus tersebut telah menjadi pijakan yang harus dipegang teguh bagi para hakim. Selanjutnya, kalau penjatuhan sanksi di bawah minimum tidak dilaksanakan, maka terdapat kekhawatiran terhadap disparitas putusan dan melukai rasa keadilan dalam masyarakat. Lebih lanjut dikatakan bahwa sebebas-bebasnya hakim harus tetap memutus menurut hukum.

Pernyataan ketiga responden di atas, dapat dikemukakan bahwa terdapat perbedaan mengenai ketentuan boleh tidaknya memutus di bawah standar minimum. Hakim Joni dan Rangki menyatakan tidak sependapat dengan anggapan bahwa hakim boleh menjatuhkan di bawah standar minimum. Sebaliknya, hakim V.Banar menyatakan setuju atau boleh menjatuhkan vonis di bawah standar minimum khusus. Pernyataan ketiga responden mempunyai dasar yuridis yang kuat.

Berdasarkan pendapat di atas, secara umum dapat diberikan tanggapan oleh penulis bahwa hakim menerapkan vonis melalui salinan putusan sepatutnya mengacu pada rumusan undang-undang, idealnya hakim memutus sekurangkurangnya sama atau melebihi standar 
minimum sebagaiman dirumuskan pada pasal-pasal tindak pidana khusus yang mengatur ketentuan minimum. Hal tersebut, penulis sependapat dengan aliran yang berpandangan klasik (aliran konservatif). Aliran tersebut berpendapat bahwa hakim dalam menetapkan undangundang terhadap peristiwa hukum sesungguhnya tidak menjalankan perannya secara mandiri. Posisi hakim hanya sebagai "penyambung lidah" atau "corong undang-undang“" (bouchedelaloi), sehingga tidak dapat merubah kekuatan hukum undang-undang, tidak dapat menambah, tidak dapat mengurangi dikarenakan bahwa undang-undang merupakan satusatunya sumber hukum positif. Dengan demikian, penulis setuju Pasal 20 AB No. 14 tahun 1970 yaitu "hakim harus mengadili menurut undang-undang kecuali ditentukan dalam Pasal 11, hakim sama sekali tidak boleh menilai anti atau keadilan dari undang-undang".

\section{Dasar Yuridis Hakim dalam Menjatuhkan Sanksi Minimum Khusus}

Sebagaimana telah dijelaskan dalam tinjauan pustaka bahwa KUHP hanya menetapkan maksimum umum, maksimum khusus, dan minimum umum. Pada Pasal 12 ayat (2) KUHP dan Pasal 18 ayat (1) KUHP telah diatur ketentuan maksimum umum dan minimum umum dalam KUHP, kemudian maksimum khususnya terdapat dalam pasal-pasalnya tanpa mengatur minimum khususnya. Sehubungan beleum diaturnya minimum khusus, maka diciptakan suatu perundang-undangan pidana khusus.

Selanjutnya, yang dimaksud dengan perundangan-undangan pidana khusus adalah semua perundang-undangan di luar KUHP beserta perundanganundangan pelengakapnya, baik perundangundangan maupun yang bukan pidana tetapi bersanksi pidana. Dasar hukum mengenai ketentuan minimum khusus diatur dalam Pasal 103 KHUP.

Substansi Pasal 103 KHUP secara implisit memberi peluang bagi pertumbuhan hukum pidana baru diluar kodifikasi. Sebagai aturan penutup, pasal tersebut disebutkan bahwa ketentuan dalam Bab I sampai Bab VIII buku tersebut juga berlaku bagi perbautanperbuatan yang oleh ketentuan perundangundangan lainnya diancam pidana, kecuali jika oleh undang-undang ditentukan lain. Makna "undang-undang ditentukan lain" dapat diartikan sebagai tindak pidana khusus.

Demikian halnya dengan Undangundang Nomor 8 Tahun 1981 Tentang Hukum Acara Pidana Pasal 284 KUHAP yang menyebutkan bahwa perundangundangan pidana khusus yang mempunyai acara tersendiri, dalam hal tersebut, 
penjelasan KUHAP menambahkan dengan kata "yang mempunyai acara tersendiri", dimaksudkan dapat memberikan kewewenangan secara khusus kepada Jaksa untuk menyidik sesuai acara khusus tersebut. Namun, tidak dapat dihindari bahwa KUHAP tidak menjelaskan secara tuntas yang mana mempunyai acara khusus yang dimaksud, sehingga ketentuan pasal tersebut dapat dianggap sebagai dasar hukum dalam penerapan sanksi minimum, walaupun tidak diatur ketentuan minimum khususnya.

Kedua pasal di atas dapat dikemukakan sebagai gambaran dasar yuridis dalam menjatuhkan sanksi minimum khusus. Sedang teknis pelaksanaan hukuman telah diatur pada masing-masing tindak pidana khusus dengan berbagai macam ancaman minimum. Lebih lanjut, ketentuan mengenai dasar yuridis hakim dalam menjatuhkan sanksi dapat mengacu pada yurisprudensi. Hal tersebut termasuk bagian dari sumber hukum formal.

Dalam mempertimbangkan beratringannya hukuman, tidak cukup hanya memperhatikan sikap individual terdakwa, seperti: memberi keterangan berbelit-belit, tidak menunjukan penyesalan atau telah berulang-ulang melakukan perbuatan pidana. Hakim wajib mempertimbangkan kaitan perbuatan tersebut dengan masyarakat dan negara, niali-nilai kemanusian, bahkan dampak secara regional atau internasional. Namun, yang menjadi perhatian khusus adalah saat hakim mempertimbangkan hal-hal meringankan, harus diartikan tidak akan dijatuhkan hukuman maksimum kecuali hal tersebut sangat tidak sebanding dengan hal-hal yang memberatkan, tetapi harus diakui bahwa adakalanya putusan hakim tidak memuaskan.

Rangkilemba mengatakan selain mengacu pada yurisprudensi hukum, penerapan sanksi pidana pada tindak pidana khusus mengancu pada peraturan perundang-undangan (KUHP dan KUHAP). Sebagai contoh dalam Pasal 63 sampai 71 KUHP, tentang perbarengan tindak pidana, dalam penjelasannya, dikatakan bahwa peraturan ancaman tidak boleh lebih dari maksimum hukuman yang terberat ditambah sepertiga sebagaiman termaktub dalam Pasal 65 ayat (2). Sedang ketentuan penerapan sanksi diatur dalam Pasal 63 KUHPdisebutkan;

(1) "Jika suatu perbuatan dalam lebih dari satu aturan pidana, maka yang dikenakan hanya salah satu di antara aturan-aturan itu; jika berbeda-beda, dikenakan yang memuat ancaman pidana pokok yang paling berat".

(2) dikatakan "Jika suatu perbuatan masuk dalam suatu aturan pidana yang umum, diatur pula dalam aturan pidana khusus, maka hanya yang khusus itulah yang diterapkan"

Upaya hakim menerapkan sanksi minimum khusus pada perkara tindak pidana khusus tetap mengacu pada 
masing-masing ancaman minimum tindak pidana tersebut yang telah tercantum dalam masing-masing pasalnya. Ancaman minimum masing-masing tindak pidana khusus terdapat beragam ancaman yang dijatuhkan.

Selain hal di atas, dapat dikemukakan bahwa yuriprudensi hakim dapat dianggap sebagai dasar penjatuhan sanksi pidana. Hal tersebut didasarkan dengan 2 (dua) alasan: Pertama, yurisprudensi merupakan bagian dari sumber hukum formal, disamping terdapat undang-undang, kebiasaan, traktat atau perjanjian internasional, dan doktrin. Kedua, dalam penjatuhan sanksi tindak pidana khusus, hakim diberi kewenangan seluas-luasnya yang tidak terikat oleh apapun dan siapapun sebagaimana dijelaskan dalam undang-undang kekuasaan kehakiman.

Yurisprudensi hakim yang dianut oleh ketiga hakim responden dalam penjatuhan sanski terdapat persamaan yakni mengacu pada peraturan perundangundangan yang berlaku dan berdasarkan keyakinan hakim melalui beberapa pertimbangan-pertimbangan hukum yang didasarkan rasa keadilan dan kepastian hukum. Pertimbangan-pertimbangan hukum antara lain mencakup pelaku tindak pidana, moral justice dan legal justice, kultur sosial yang eksis dalam masyarakat, usia pelaku, dan kondisi sewaktu kejahatan dilakukan oleh terdakwa.
Walaupun hakim diwajibkan agar dengan sungguh-sungguh memperhatikan pertimbangan-pertimbangan hukum di atas, tetapi sebagai kasus konkrit, keadilan harus diwujudkan adalah keadilan bagi pihak yang berperkara atau yang terkena perkara. Tugas utama hakim adalah bertanggungjawab memberi keadilan kepada yang berperkara bukan masyarakat yang tidak terkait dengan perkara.

Penjelasan diatas dapat dikemukakan bahwa dasar yuridis penjatuhan sanksi minimum khusus didasarkan pada peraturan perundang-undangan dan yurisprudensi. Peraturan perundangundangan antara lain mencakup Pasal 103 KUHP dan Pasal 284 KUHAP dan yurisprudensi dalam artian menemukan hukum, bukan menciptakan hukum.

\section{KESIMPULAN DAN SARAN}

Berdasarkan hasil penelitian dan pembahasan, maka dapat disimpulkan halhal sebagai berikut.

\section{A. Kesimpulan}

1. Peranan hakim dalam penerapan sanksi minimum dalam tindak pidana khusus pada proses peradilan pidana sangat besar, yaitu sebagai pemberi putusan akhir, hakim berpedoman pada peraturan undang-undang. Dengan demikian, maka penulis berpendapat 
bahwa hakim tidak boleh menjatuhkan sanksi di bawah standar minimum. Dengan alasan bahwa negara Indonesia menganut Sistem Kontinental yakni hakim (sebagai pedoman pemidanaan) terikat oleh undang-undang (aliran konservatif). Hal tersebut, sebagai realisasi asas the binding persuasive of precedent. Selain itu, konteks sanksi minimum yang terdapat dalam rumusan pasal terhadap tindak pidana khusus, secara terang dan jelas, terdapat pernyataan sanksi pidana yang memuat ketentuan maksimal dan minimal, sehingga tidak memerlukan penafsiran lanjutan.

2. Selain mengacu Pasal 103 KUHP dan 284 ayat (1) dan (2) KUHAP, dasar yuridis penerapan sanksi, hakim mengacu pada peraturan perundangundangan tindak pidana khusus yang mengatur ketentuan minimum khusus. Selain kedua pasal di atas, yurisprudensi dapat digunakan sebagai dasar yuridis dalam penjatuhan sanksi, dengan catatan, tetap mengacu ketentuan minimum sekurangkurangya sama atau di atas minimum.

\section{B. Saran}

1. Penerapan sistem minimum khusus dalam tindak pidana khusus, hendaknya disertai dengan aturan atau pedoman pemidanaan dalam ketentuan umum
KUHP dengan kriteria yang lebih jelas serta lebih spesifik, sehingga tidak akan menimbulkan permasalahanpeermasalahan apabila berhadapan dengan perkara-perkara yang berkaitan dengan hal-hal yang meringankan dan memberatkan terdakwa.

2. Untuk menjamin diterapkannya pidana minimum khusus, perlu diciptakan undang-undang tentang Pengawasan Penegakan Hukum terkait dengan pelaksanaan tugas masing-masing lembaga yang berwenang dalam prosesi peradilan, seperti halnya di negara Jepang. Dengan demikian, terdapat sanksi khusus bagi penuntut umum dan hakim yang memvonis di bawah minimum khusus sebagaimana diatur dalam tindak pidana khusus.

3. Pendidikan pembentukan hakim dan jaksa dilakukan secara terpadu dan lebih lama. Calon-calon hakim dan jaksa harus melalui tes yang ketat tentang pengetahuan hukum, kesehatan badan dan jiwa. Sebagai contoh, pendidikan jaksa dan hakim di Nederland berlangsung 6 (enam) tahun sesudah sarjana dan terpadu antara calon hakim dan jaksa, sehingga diperoleh kesatuan penafsiran hukum. Sistem rekrutmen dan pendidikan hakim dan jaksa yang terpisah tidak menguntungkan sistem peradilan pidana terpadu. 


\section{DAFTAR PUSTAKA}

\section{BUKU}

Bambang Sutiyoso, Sri Hastuti Puspitasari, Aspek-aspek Perkembangan Kekuasaan Kehakiman Di Indonesia, Pengatar: Prof.Dr. Jimly Asshidqi, Penjelasan atas Undang-undang Republik Indonesia Nomor 4 Tahun 2004 Tentang Kekuasaan Kehakiman, UII Press, Yogyakarta, 2005

Barda Nawawi Arief, Bunga Rampai Kebijakan Hukum Pidana, Citra Aditya Bakti, Bandung, 2002

Gregorius Aryadi, Putusan Hakim Dalam Perkara Pidana, Universitas Atma Jaya Yogyakarta, 1995

ISoelidarmi, S.H. ,Kumpulan Putusan Kontraversial dari Hakim/Majelis Kontraversial, UII Press, Yogyakarta, 2002.

\section{PERATURAN}

PERUNDANG-

\section{UNDANGAN}

Undang-undang No. 4 Tahun 2004 Tentang Kekuasaan Kehakiman

Undang-undang No. 5 Tahun 2004 Tentang Perubahan Atas Undangundang No. 14 Tahun 1985 Tentang Mahkamah Agung.

Undang-undang No. 20 Tahun 2001 Perubahan Atas Undang-undang No.31 Tahun 1999 Tentang Pemberantasan Tindak Pidana Korupsi.

Undang-undang No.5 Tahun 1997 Tentang Psikotropika

Undang-undang No. 9 Tahun 1976 Tentang Narkotika
Undang-undang No. 39 Tahun 1999 Tentang Hak Asasi Manusia

Undang-undang No. 23 Tahun 2002 Tentang Perlindungan Anak

Instruksi Presiden No. 3 Tahun 2002 Tentang Penyalahgunaan dan Penanggulangan Peradaran Gelap Narkotika, Psikotropika, Prekursor, dan Zat Adiktif Lainnya. 